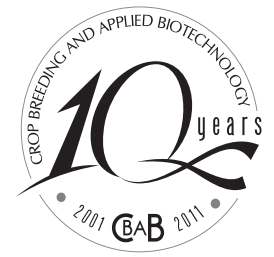

\title{
Characterization of sweet cassava accessions based on molecular, quantitative and qualitative data
}

Eduardo Alano Vieira ${ }^{1}{ }^{*}, J_{0}$ sefino de Freitas Fialho ${ }^{1}$, Fábio Gelape Faleiro ${ }^{1}$, Graciele Bellon ${ }^{1}$, Kenia Graciele da Fonseca ${ }^{1}$, Luiz Joaquim Castelo Branco Carvalho ${ }^{2}$, Marilia Santos Silva ${ }^{1}$, Silvana Vieira de Paula-Moraes ${ }^{1}$, Charles Martins de Oliveira ${ }^{1}$ and Marcelo Luiz Denke ${ }^{1}$

Received 3 August 2010

Accepted 30 September 2010

\begin{abstract}
The purpose of this study was to estimate the genetic divergence in sweet cassava accessions by molecular markers and quantitative and qualitative characters, as well as determine the correlation between these estimates. Sixteen sweet cassava accessions of the Regional Cassava Germplasm Bank of the Cerrado were evaluated under field conditions, for 13 quantitative and 33 qualitative characters. In the laboratory, the accessions were evaluated with RAPD markers. Subsequently, matrixes of genetic dissimilarity/distance among the accessions were estimated based on molecular markers and quantitative and qualitative characters. Besides, the significance of the correlation between the matrixes was estimated. The RAPD, qualitative and quantitative data indicated the existence of high divergence among the accessions. The divergences estimated by molecular markers and by quantitative traits were weakly associated with each other and moderately with the divergence estimated by qualitative characters.
\end{abstract}

Key words: Manihot esculenta Crantz, genetic resources, breeding, genetic variability.

\section{INTRODUCTION}

Cassava (Manihot esculenta Crantz) is grown mainly for its starchy tuberous roots (El-Sharkawy 2003) and stands out as a major energy source in the diet of populations in developing countries (Cock 1985). The species is important for the food security of these populations, particularly in view of: i) the rusticity and ability to produce high starch amounts under conditions which other species cannot even survive in ii) versatility of use (for fresh food, food industry, general industry, animal feed, among others), iii) flexibility in planting and harvesting, and iv) the sociocultural importance cassava has for these populations (Colombo et al. 2000, Mkumbira et al. 2003, Ceballos et al. 2004).

The species has a marked characteristic, which is the storage of cyanogenic glycosides (CG) in all tissues except the seeds. Among these cyanogenic glycosides, the most abundant is linamarin $(85 \%)$ produced in the leaves and transported to the roots; when in contact with the enzyme linamarase it releases hydrogen cyanide $(\mathrm{HCN})$ (Andersen et al. 2000, El-Sharkawy 2003). At HCN concentrations of more than $100 \mathrm{ppm}$ in fresh cassava roots, the plant is toxic for human fresh consumption and must be processed before consumption to eliminate the excess of this substance (Bolhuis et al. 1954). Accessions with high HCN concentrations are called bitter and are mainly consumed as flour, starch, glucose, among others. In turn, the accessions with low HCN levels (less than $100 \mathrm{ppm}$ in fresh roots), are known as sweet cassava, manioc, among others, and can be consumed cooked or processed.

The market for sweet cassava could expand greatly in Brazil, especially with regard to pre-cooked and minimally

\footnotetext{
${ }^{1}$ Embrapa Cerrados, P.O. Box 08223, 73.310-970, Planaltina, DF, Brazil. *E-mail: vieiraea@cpac.embrapa.br

${ }^{2}$ Embrapa Cenargen, P.O. Box 02372, 70.770-970, Brasília, DF, Brazil
} 
processed cassava. However, this potential growth implies the existence of varieties that combine low $\mathrm{HCN}$ root levels with high root yield and good cooking quality (Borges et al. 2002, Vieira et al. 2009). This challenge must be addressed by genetic improvement and the selection of specific genetic constitutions for fresh consumption. This in turn, implies the existence of genetic variability and phenotypic and detailed knowledge of genotypes that may be used as parents.

In Brazil, the possible center of origin and diversity of cassava (Manihot esculenta Crantz) (Olsen 2004), the genetic and phenotypic variability of the species are high (Carvalho and Schaal 2001, Ferreira et al. 2008, Nick et al. 2008, Vieira et al. 2008), which can be exploited in breeding programs. One of the ways of exploiting germplasm is based on the estimation of genetic divergence in a set of genotypes. For this purpose, molecular markers (Carvalho and Schaal 2001, Ferreira et al. 2008) or phenotypic characters (Mkumbira et al. 2003, Nick et al. 2008) can be used separately or in combined analyses (Vieira et al. 2008). Compared to phenotypic traits, molecular markers have the advantage of not being influenced by the environment, but have the disadvantage of accessing the genome as a whole and not only the regions responsible for the expression of traits of interest.

Despite the importance of studying genetic diversity, there are no published reports of such studies on sweet cassava accessions, based on the combined use of molecular and morpho-agronomic markers and complementary strategies to guide germplasm conservation and use.

The purpose of this study was to estimate the genetic divergence among accessions of sweet cassava by molecular markers and quantitative and qualitative traits and to determine the correlation between these estimates.

\section{MATERIAL AND METHODS}

Between October 11, 2006 and October 6, 2007, 16 sweet cassava accessions of the Regional Cassava Germplasm Bank of the Cerrado (BGMC) (Table 1) were evaluated in the field in the municipality of Planaltina, DF (lat $15^{\circ} 35^{\prime}$ 30 " S, long $47^{\circ} 42^{\prime} 30^{\prime}$ 'W, $1000 \mathrm{~m}$ asl). The experiment was arranged in a randomized block design with three replications, where each plot consisted of four rows with 10 plants, spaced $1.20 \mathrm{~m}$ between rows and $0.80 \mathrm{~m}$ between plants, and the 16 central plants per plot were evaluated. The selection of genotypes for propagation and the cultural practices were performed according to the recommendations of the system of cassava production for the Cerrado region by Souza and Fialho (2003).

The following quantitative traits were measured in the field: i) plant height in $\mathrm{m}(\mathrm{PH})$; ii) height of first branching in $\mathrm{m}$ (HFB); iii) shoot weight without original stem cutting in $\mathrm{kg} \mathrm{ha}^{-1}$ (ShW); iv) the original stem cutting weight in $\mathrm{kg} \mathrm{ha}^{-1}$ (StW); v) root yield in $\mathrm{kg} \mathrm{ha}^{-1}(\mathrm{RY})$; vi) root starch percentage by the method of hydrostatic balance (RSt), described by Grossmann and Freitas (1950); vii) cooking time in minutes (CT) according to the method described by Borges et al. (2002); viii) length of the leaf lobe in $\mathrm{cm}$ (LLL) by measuring a leaf from the mid-third of each plant of 16 central plants per plot six months after planting; ix) width of the leaf lobe in $\mathrm{cm}$ (WLL) by measurement of a leaf from the mid-third per plant of 16 central plants per plot six months after planting; $x$ ) petiole length in $\mathrm{cm}$ (PL) by measuring a leaf from the mid-third per plant of 16 central plants per plot six months after planting; xi) the average number of nymphs and adults of lacebug (Vatiga illudens Drake) (NL) obtained by counting the number of nymphs and adults of lacebug in the three assessments (18.12.2006, 10.01.2007 and 06.03.2007) of three plants sampled per plot; xii) incidence of cassava bacterial blight (Xantomonas axonopodis pv manihotis) in percentage (BBI) by counting the total number of plants with disease symptoms in the plots in two evaluations (03/13/07 and 05/18/07); and xiii) severity of cassava bacterial blight (BBS) through the evaluation of three plants per plot in both evaluations (03/13/07 and 05/18/ 07), based on the 1-5 grade scale described by Ramos and Takatsu (1987), where 1: no visible symptoms; 2: only water-soaked angular spots on leaves; 3: water-soaked angular spots on leaves and pus on the stem; 4: water-soaked angular spots on leaves, pus on the stem and leaf drop; 5: descendent death (i.e. leaves dying off from top to bottom of the plant, in contrast to healthy plants, where leaves die off from bottom to top). The data were subjected to analysis of variance and means were compared based on the mean grouping test of Scott and Knott (1974) at $5 \%$ probability using software Genes (Cruz 2001). The BBS data were transformed to square root of $\mathrm{x}$, prior to analysis of variance. At harvest the amount of hydrogen cyanide (HCN) in roots $\left(\mathrm{mg} \mathrm{kg}^{-1}\right)$ was also determined by the qualitative method described by Willians and Edwards (1980), in five randomly sampled roots per plot. Since the $\mathrm{HCN}$ data were qualitative, they were not included in the statistical analyses. Later, Mahalanobis' distance $\left(\mathrm{D}^{2}\right)$ (Mahalanobis 1936) among 16 cassava accessions was 
estimated, based on the 13 quantitative traits measured, using Genes (Cruz 2001).

The accessions were evaluated based on 33 qualitative traits measured as recommended by Fukuda and Guevara (1998), namely: i) color of the leaf apex; ii) pubescence of apical shoot; iii) shape of central lobe; iv) petiole color v) color of stem cortex; vi) external stem color; vii) phyllotaxis length; viii) presence of root peduncle; ix) external root color; $\mathrm{x}$ ) color of root cortex; $\mathrm{xi}$ ) root pulp color; xii) texture of root epidermis; xiii) presence of flowering; xiv) mature leaf color; $x v$ ) number of lobes; $x v i$ ) epidermis color of the stem; xvii) stem growth habit; $x$ viii) terminal branch color of mature plants; $\mathrm{xix}$ ) root constriction; $\mathrm{xx}$ ) rib color; $\mathrm{xxi}$ ) petiole position; xxii) prominence of leaf scars; $x$ xiii) stipule length; xxiv) stipule edges; xxv) branching habit; xxvi) sinuosity of leaf lobe; xxvii) root shape; xxviii) plant type; $\mathrm{xxix}$ ) average root length; $\mathrm{xxx}$ ) root diameter; $\mathrm{xxxi)}$ detachment of root skin; xxxii) detachment of root cortex; and xxxiii) root position. Based on 27 qualitative characters with variability among accessions, the genetic similarity among accessions was estimated by the complement of the simple index of coincidence, using Genes (Cruz 2001).

The DNA used in the analysis with RAPD markers was extracted from leaves in the intermediate maturity stage by the method of CTAB (2.8\%), with modifications proposed by Faleiro et al. (2003). The DNA was quantified based on absorbance at $260 \mathrm{~nm}$ and purity analysis by measuring the absorbance ratio at $260 / 280 \mathrm{~nm}$. DNA samples of each accession were amplified to obtain RAPD markers as described by Costa et al. (2005). To obtain the markers 11 decamer primers were used (Operon Technologies Inc., Alameda, CA, USA): OPD 02, OPE 12, OPF 08, OPG (05, 08, 09 and 15) and $\mathrm{OPH}(04,13$ and 15). The amplified fragments were separated by electrophoresis of four hours at 90 volts, on agarose gel $(1.2 \%)$, stained with ethidium bromide submerged in TBE buffer $(90 \mathrm{mM}$ Tris-borate, $1 \mathrm{mM}$ EDTA). At the end of the run, gels were photographed under UV light and the RAPD markers classified according to the presence (1) or absence ( 0 ) of bands. The data matrices were used to estimate the genetic similarity among accessions, based on the complement of Jaccard's similarity coefficient (Jaccard 1908).

On the basis of genetic distances/dissimilarities derived from the analysis with quantitative and qualitative traits and RAPD, three dendrograms were drawn by the unweighted pair-group method using arithmetic averages (UPGMA). The adjustment of distance/dissimilarity matrices and the respective dendrograms were estimated by the cophenetic correlation coefficient (r), according to Sokal and Rohlf (1962), using the program NTSYS pc 2.1 (Rohlf 2000).

The significance of the association between distance matrices obtained by RAPD analysis, quantitative traits and qualitative characters was estimated by means of the Mantel matrix comparison with 1000 permutations (Mantel 1967), using NTSYS pc 2.1 (Rohlf 2000).

\section{RESULTS AND DISCUSSION}

The variability among the sweet cassava accessions for all quantitative traits was demonstrated by significant differences $(\mathrm{P}<0.05)$ in the $\mathrm{F}$ test (Table 2$)$. Wide variability was expected, since improved and unimproved accessions from different origins were evaluated (Table 1), similarly as reported for cassava in studies by Nick et al. (2008) and Vieira et al. (2008). The coefficients of variation ranged from $3.26 \%$ for PL to $33.47 \%$ for BBI, indicating high experimental accuracy (Table 2). Variability in the HCN root content was also detected, although the values of all accessions were below 100 ppm, confirming that these accessions are sweet cassava and can be consumed fresh (Table 2).

The quantitative trait with the highest number of distinct classes in the test of mean comparison (six classes) was ShW, with averages from $26111 \mathrm{~kg} \mathrm{ha}^{-1}$ to $8163 \mathrm{~kg} \mathrm{ha}^{-1}$ of the accessions BGMC 1246 and BGMC 1254, respectively (Table 2). ShW is a very important trait in the recommendation for planting of cassava accessions, since it indicates the potential to produce stem cuttings and the possibility of using part of the shoots as protein source in animal feed (El-Sharkawy 2003, Ceballos et al . 2004). The number of classes in the comparison test of means was lowest for the trait cooking time (two classes), ranging from 19.33 min to $30.33 \mathrm{~min}$, for accessions BGMC 751 and BGMC 34, respectively (Table 2). CT is very important for sweet accessions, since it is closely related to the culinary quality (Ceballos et al. 2004, Vieira et al. 2009). For the trait RY, which is as important as CT for cultivar recommendation of sweet cassava, the accessions were divided into four groups i) BGMC 962, BGMC 1096, BGMC 1246, BGMC 1291, and BGMC 1341; ii) BGMC 1289, BGMC 753, BGMC 982, BGMC 1292, BGMC 764, and BGMC 1254; iii) BGMC 1290 and BGMC 34; and iv) BGMC 751, BGMC 1266 and BGMC 1250, with a range of variation of $13263 \mathrm{~kg} \mathrm{ha}^{-1}$, higher than the average cassava productivity in the 
Characterization of sweet cassava accessions based on molecular, quantitative and qualitative data

Table 1. Sweet cassava accessions of this study with the respective popular names and sampling sites/origin

\begin{tabular}{|c|c|c|}
\hline Accessions $^{1}$ & Popular name & Sampling sites/origin \\
\hline BGMC 982 & Iapar 19/Pioneira & IAPAR - Londrina (PR) \\
\hline BGMC 753 & IAC 756-70/Japonesinha & IAC - Campinas (SP) \\
\hline BGMC 1289 & Taquara Amarela & Planaltina (DF) \\
\hline BGMC 1290 & Taquara Amarela 1 & Planaltina (DF) \\
\hline BGMC 1291 & Taquara Amarela 2 & Planaltina (DF) \\
\hline BGMC 1292 & Taquara Amarela 3 & Planaltina (DF) \\
\hline BGMC 1266 & Flores de Goiás & Flores de Goiás (GO) \\
\hline BGMC 34 & IAC 24-2/Mantiqueira & IAC - Campinas (SP) \\
\hline BGMC 751 & Japonesa & Brasília (DF) \\
\hline BGMC 1246 & Americana & Brazlândia (GO) \\
\hline BGMC 764 & Sem denominação & Sobradinho (DF) \\
\hline BGMC 1254 & Buriti & Planaltina (DF) \\
\hline BGMC 1096 & IAC $59-210$ & IAC - Campinas (SP) \\
\hline BGMC 1341 & Pioneira diferente & Unaí (MG) \\
\hline BGMC 962 & Vassourinha & Morrinhos (GO) \\
\hline BGMC 1250 & Branca de Unaí & Unaí (MG) \\
\hline
\end{tabular}

Cerrado region, which is $13000 \mathrm{~kg} \mathrm{ha}^{-1}$, according to Souza and Fialho (2003). High variability was detected for most traits, as demonstrated by the high ranges of variation (Table 2), which shows that the accession set contains enough phenotypic variation for traits of agronomic interest to be exploited in breeding programs of the crop.

The genetic distance estimated by the quantitative traits revealed that the closest accessions were BGMC 1292 and BGMC 1289, both local varieties of the group Taquara Amarela from Planaltina, DF, while the longest distance was observed among accessions BGMC 1254 and BGMC 1292, two local varieties collected in Planaltina, DF as well (Table 1). In a visual analysis of Figure 1A, using the average distance as cutoff, the accessions were clustered in three groups; the first consisted of the accessions BGMC 34, BGMC 751, BGMC 764, BGMC 1096, BGMC 753, BGMC 1266, BGMC 1246, and BGMC 1250; the second of BGMC 982, BGMC 1341, BGMC 1290, BGMC 1292, BGMC 1289, and BGMC 1291; and the third only with BGMC 1254, which showed high divergence compared to the other accessions, particularly due to higher means of PH, HFB, CT, BBI and BBS and lower ShW and StW (Table 2, Figure 1A). The cophenetic correlation coefficient of the dendrogram $(r=0.92)$ revealed the good adjustment of the graphical representation of distances with the distance matrix of Mahalamobis, confirming the inferences based on the visual assessment of Figure 1A.

For twenty seven ( $82 \%$ ), of the 33 qualitative characters analyzed, variability among the cassava accessions was observed, while only six qualitative characters had no variability, since all accessions had long and sharp stipules, prominent leaf scars, straight growth habit of the stem and easy removal of the root skin and cortex. This indicates broad morphological divergence and efficiency of these characters in the estimation of genetic diversity in cassava, as also reported by Mkumbira et al. (2003) and Vieira et al. (2008). The dissimilarity estimated by the qualitative characters showed that the most similar accessions were: i) BGMC 1291 and BGMC 1292, two local varieties of the group Taquara Amarela, from Planaltina, DF, and ii) BGMC 982 and BGMC 1341, of which the first is a variety recommended for cultivation in the Cerrado region and popularly known as Pioneira, while the second is a local variety from Unai, Minas Gerais, popularly known as "Pioneira diferente" because of the great phenotypic similarity with Pioneira (Table 1, Figure 1B). The greatest differences were observed between BGMC 1254 and accessions BGMC 982 and BGMC 1266.

Based on a visual analysis of Figure $1 \mathrm{~B}$, using the mean dissimilarity as cutoff, five groups of accessions were established: i) BGMC 34, BGMC 764, BGMC 1096, and BGMC 1246; ii) BGMC 751, BGMC 1290, BGMC 1291, BGMC 1292, BGMC 1289, BGMC 962, BGMC 982, and BGMC 1341; iii) BGMC1250 and BGMC 1266; iv) BGMC 753; and v) BGMC 1254. The high cophenetic correlation coefficient of the dendrogram $(r=0.89)$ suggested a good adjustment of the graphical dissimilarity representation with the original dissimilarity matrix, reinforcing the inferences based on the visual assessment of Figure 1B. 
Noble 2. Comparison of means and summary of analysis of variance of the traits plant height in $\mathrm{m}$ (PH), height of first branching in $\mathrm{m}$ (HFB), shoot weight without origina stem cutting in $\mathrm{kg} \mathrm{ha}^{-1}(\mathrm{ShW})$, the original stem cutting weight in $\mathrm{kg} \mathrm{ha}^{-1}(\mathrm{StW})$, root yield in $\mathrm{kg} \mathrm{ha}^{-1}(\mathrm{RY})$, root starch percentage (RSt), cooking time in minutes $(\mathrm{CT})$, mean number of nymphs and adults of lacebug (Vatiga illudens Drake) (NL), incidence of cassava bacterial blight in percent (BBI), severity of cassava bacterial blight (BBS), length of the leaf lobe in $\mathrm{cm}$ (LLL), width of the leaf lobe in $\mathrm{cm}$ (WLL), length do petiole in $\mathrm{cm}$ (PL) and HCN content in ppm in roots in ppm (HCN) of $16 \mathrm{sweet}$ cassava accessions

\begin{tabular}{|c|c|c|c|c|c|c|c|c|c|c|c|c|c|c|}
\hline Accession & PH & HFB & ShW & StW & RY & RSt & CT & NL & BBI & BBS $^{2}$ & LLL & WLL & PL & $\mathrm{HCN}^{3}$ \\
\hline BGMC 34 & $2.00 \mathrm{~B}^{1}$ & $0.93 \mathrm{C}$ & $17361 \mathrm{C}$ & $2830 \mathrm{E}$ & $14097 \mathrm{C}$ & $27.38 \mathrm{C}$ & $30.33 \mathrm{~A}$ & $16.80 \mathrm{~B}$ & $0.01 \mathrm{E}$ & $1.11 \mathrm{D}$ & $20.32 \mathrm{C}$ & $6.01 \mathrm{~A}$ & $37.05 \mathrm{~B}$ & $15-25$ \\
\hline BGMC 751 & $1.60 \mathrm{D}$ & $0.70 \mathrm{D}$ & $16282 \mathrm{D}$ & $2627 \mathrm{E}$ & $12802 \mathrm{D}$ & $29.44 \mathrm{~B}$ & $19.33 \mathrm{~B}$ & $21.46 \mathrm{~A}$ & $0.00 \mathrm{E}$ & $1.00 \mathrm{D}$ & $17.30 \mathrm{D}$ & $5.90 \mathrm{~A}$ & $39.88 \mathrm{~A}$ & $15-25$ \\
\hline BGMC 753 & $1.83 \mathrm{C}$ & $0.76 \mathrm{D}$ & $17396 \mathrm{C}$ & $3567 \mathrm{C}$ & $18516 \mathrm{~B}$ & $26.16 \mathrm{D}$ & $23.00 \mathrm{~B}$ & $25.39 \mathrm{~A}$ & $0.00 \mathrm{E}$ & $1.00 \mathrm{D}$ & $16.76 \mathrm{D}$ & $3.22 \mathrm{D}$ & $28.37 \mathrm{D}$ & $15-25$ \\
\hline BGMC 764 & $1.67 \mathrm{C}$ & $1.00 \mathrm{C}$ & $14057 \mathrm{E}$ & $3015 \mathrm{D}$ & $16436 \mathrm{~B}$ & $24.75 \mathrm{D}$ & $28.00 \mathrm{~A}$ & $21.98 \mathrm{~A}$ & $0.00 \mathrm{E}$ & $1.00 \mathrm{D}$ & $19.66 \mathrm{C}$ & $5.88 \mathrm{~A}$ & $33.45 \mathrm{C}$ & $15-25$ \\
\hline BGMC 982 & $1.87 \mathrm{C}$ & $0.97 \mathrm{C}$ & $20510 \mathrm{~B}$ & $3629 \mathrm{C}$ & $17543 \mathrm{~B}$ & $28.43 \mathrm{C}$ & $20.00 \mathrm{~B}$ & $19.59 \mathrm{~A}$ & $0.01 \mathrm{E}$ & $1.33 \mathrm{D}$ & $24.34 \mathrm{~A}$ & $3.33 \mathrm{D}$ & $31.74 \mathrm{C}$ & $10-15$ \\
\hline BGMC 1096 & $2.30 \mathrm{~A}$ & $1.00 \mathrm{C}$ & $21640 \mathrm{~B}$ & $4460 \mathrm{~B}$ & $24475 \mathrm{~A}$ & $26.40 \mathrm{D}$ & $27.33 \mathrm{~A}$ & $22.35 \mathrm{~A}$ & $0.00 \mathrm{E}$ & $1.00 \mathrm{D}$ & $17.28 \mathrm{D}$ & $5.34 \mathrm{~B}$ & $33.04 \mathrm{C}$ & $10-15$ \\
\hline BGMC 1341 & $2.00 \mathrm{~B}$ & $0.87 \mathrm{C}$ & 19472 B & $3812 \mathrm{C}$ & $19171 \mathrm{~A}$ & $27.83 \mathrm{C}$ & $24.33 \mathrm{~B}$ & $16.78 \mathrm{~B}$ & $0.00 \mathrm{E}$ & $1.00 \mathrm{D}$ & $22.49 \mathrm{~B}$ & $3.15 \mathrm{D}$ & $33.33 \mathrm{C}$ & $10-15$ \\
\hline BGMC 1246 & $2.70 \mathrm{C}$ & $0.57 \mathrm{D}$ & $26111 \mathrm{~A}$ & $5390 \mathrm{~A}$ & 20399 A & $26.59 \mathrm{D}$ & $24.00 \mathrm{~B}$ & $7.46 \mathrm{~B}$ & $0.13 \mathrm{C}$ & $1.78 \mathrm{C}$ & $19.16 \mathrm{C}$ & $5.98 \mathrm{~A}$ & $33.84 \mathrm{C}$ & $15-25$ \\
\hline BGMC 1250 & $2.37 \mathrm{~A}$ & $1.90 \mathrm{~B}$ & $12938 \mathrm{E}$ & $3151 \mathrm{D}$ & $11212 \mathrm{D}$ & $27.42 \mathrm{C}$ & $24.00 \mathrm{~B}$ & $25.60 \mathrm{~A}$ & $0.07 \mathrm{D}$ & $1.78 \mathrm{C}$ & $18.67 \mathrm{C}$ & $5.56 \mathrm{~B}$ & $29.28 \mathrm{D}$ & $15-25$ \\
\hline BGMC 1254 & $2.37 \mathrm{~A}$ & $2.37 \mathrm{~A}$ & $8163 \mathrm{~F}$ & $2845 \mathrm{E}$ & $16355 \mathrm{~B}$ & $27.68 \mathrm{C}$ & $29.33 \mathrm{~A}$ & $12.27 \mathrm{~B}$ & $0.43 \mathrm{~A}$ & $3.00 \mathrm{~A}$ & $20.02 \mathrm{C}$ & $4.87 \mathrm{C}$ & $34.39 \mathrm{C}$ & $25-40$ \\
\hline BGMC 1266 & $1.93 \mathrm{~B}$ & $0.97 \mathrm{C}$ & $14326 \mathrm{E}$ & $3767 \mathrm{C}$ & $12080 \mathrm{D}$ & $31.38 \mathrm{~A}$ & $24.00 \mathrm{~B}$ & $16.05 \mathrm{~B}$ & $0.00 \mathrm{E}$ & $1.00 \mathrm{D}$ & $21.06 \mathrm{~B}$ & $6.09 \mathrm{~A}$ & $39.48 \mathrm{~A}$ & $15-25$ \\
\hline BGMC 1290 & $1.57 \mathrm{D}$ & $0.97 \mathrm{C}$ & $14652 \mathrm{E}$ & $3107 \mathrm{D}$ & $14739 \mathrm{C}$ & $28.02 \mathrm{C}$ & $26.33 \mathrm{~A}$ & $16.28 \mathrm{~B}$ & $0.00 \mathrm{E}$ & $1.00 \mathrm{D}$ & $23.28 \mathrm{~A}$ & $3.33 \mathrm{D}$ & $33.25 \mathrm{C}$ & $10-15$ \\
\hline BGMC 1291 & $1.37 \mathrm{D}$ & $0.77 \mathrm{D}$ & $13932 \mathrm{E}$ & $3594 \mathrm{C}$ & $19936 \mathrm{~A}$ & $28.09 \mathrm{C}$ & $29.66 \mathrm{~A}$ & $14.04 \mathrm{~B}$ & $0.00 \mathrm{E}$ & $1.00 \mathrm{D}$ & $22.10 \mathrm{~B}$ & $2.29 \mathrm{D}$ & $34.22 \mathrm{C}$ & $10-15$ \\
\hline BGMC 1292 & $1.47 \mathrm{D}$ & $0.90 \mathrm{C}$ & $16059 \mathrm{D}$ & $3542 \mathrm{C}$ & $16458 \mathrm{~B}$ & $29.47 \mathrm{~B}$ & $28.66 \mathrm{~A}$ & $12.94 \mathrm{~B}$ & $0.00 \mathrm{E}$ & $1.00 \mathrm{D}$ & $23.25 \mathrm{~A}$ & $3.34 \mathrm{D}$ & $35.45 \mathrm{~B}$ & $10-15$ \\
\hline BGMC 1289 & $1.60 \mathrm{D}$ & $0.83 \mathrm{C}$ & $18229 \mathrm{C}$ & $4141 \mathrm{~B}$ & $18594 \mathrm{~B}$ & $29.03 \mathrm{~B}$ & $26.66 \mathrm{~A}$ & $23.31 \mathrm{~A}$ & $0.00 \mathrm{E}$ & $1.00 \mathrm{D}$ & $23.00 \mathrm{~A}$ & $3.45 \mathrm{D}$ & $35.31 \mathrm{~B}$ & $15-25$ \\
\hline BGMC 962 & $1.57 \mathrm{D}$ & $0.70 \mathrm{D}$ & $12297 \mathrm{E}$ & $3067 \mathrm{D}$ & $21849 \mathrm{~A}$ & $30.52 \mathrm{~A}$ & $25.00 \mathrm{~B}$ & $21.94 \mathrm{~A}$ & $0.22 \mathrm{~B}$ & $2.44 \mathrm{~B}$ & $20.14 \mathrm{C}$ & $2.84 \mathrm{D}$ & $30.69 \mathrm{D}$ & $15-25$ \\
\hline General mean & 1.83 & 1.01 & 16464 & 3534 & 16919 & 28.04 & 25.63 & 18.39 & 0.06 & 1.34 & 20.56 & 4.48 & 33.93 & - \\
\hline Range $^{4}$ & 1.00 & 1.80 & 17948 & 2763 & 13263 & 6.63 & 11.00 & 18.14 & 0.43 & 2.00 & 7.58 & 3.25 & 11.51 & - \\
\hline \multicolumn{15}{|c|}{ Sources of variation $(\mathrm{df})$} \\
\hline $\mathrm{Ms}_{\text {accessions }}(15)$ & $0.30^{*}$ & $0.64^{*}$ & $53802095^{*}$ & $1485039^{*}$ & $31077943^{*}$ & $8.53^{*}$ & $31.95^{*}$ & $79.57^{*}$ & $0.04^{*}$ & $1.11^{*}$ & $16.77^{*}$ & $5.13^{*}$ & $30.03^{*}$ & - \\
\hline $\mathrm{MS}_{\text {error }}(30)$ & 0.02 & 0.01 & 2016379 & 41281 & 2012113 & 1.16 & 12.78 & 31.02 & 0.0003 & 0.05 & 0.67 & 0.05 & 1.22 & - \\
\hline CV (\%) & 7.77 & 9.60 & 8.62 & 5.75 & 8.38 & 3.85 & 13.95 & 30.29 & 33.47 & 16.62 & 3.97 & 5.17 & 3.26 & - \\
\hline
\end{tabular}

${ }^{1}$ Means followed by equal letters, in the columns, belong to the same cluster by the test of Scott and Knott at $5 \%$ probability. ${ }^{2}$ Grades on the scale described by Ramos and Takatsu (1987). ${ }^{3}$ Evaluated at harvest, by the qualitative method described by Willians and Edwards (1980). ${ }^{4}$ Difference between highest and lowest mean. ${ }^{*}$ Significant at $5 \%$ probability by the $\mathrm{F}$ test. 
A

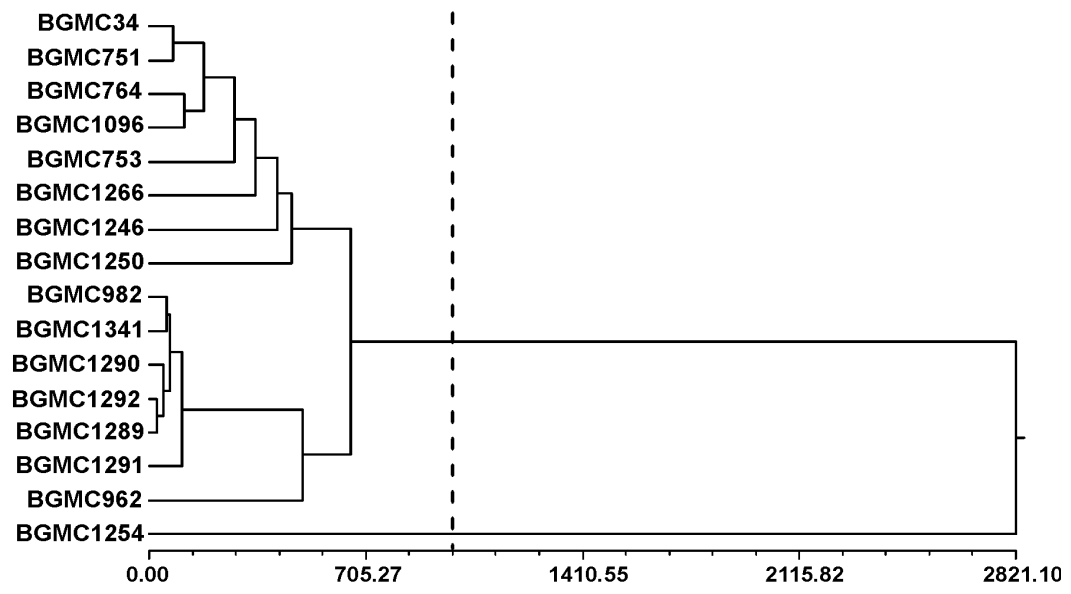

B

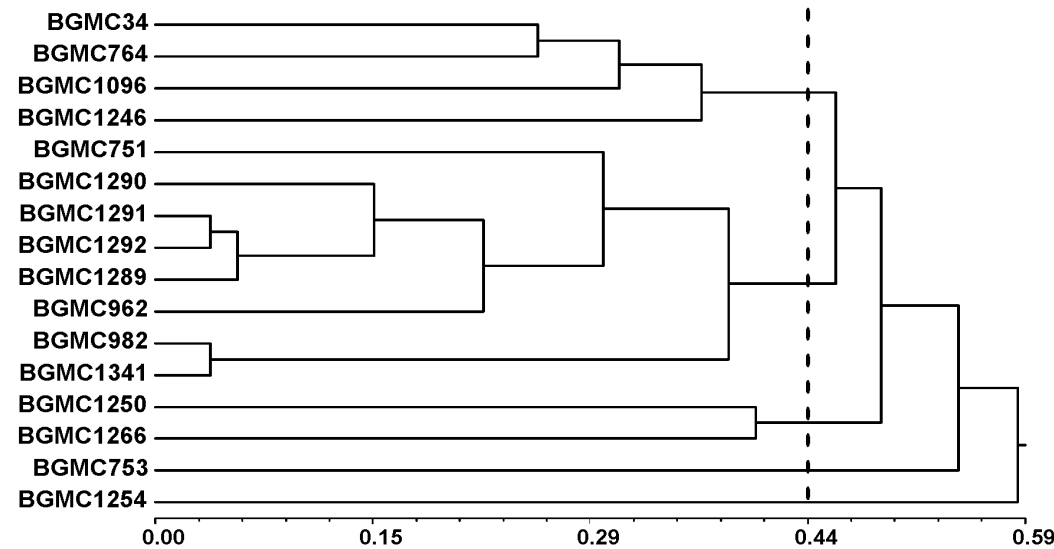

C

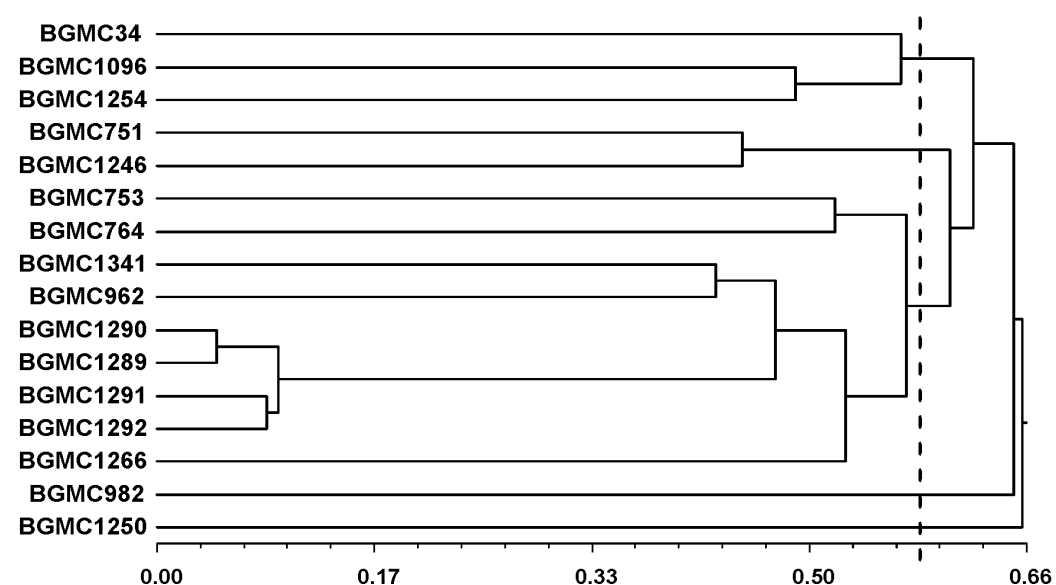

Figure 1. Dendrograms derived from the grouping analysis of 16 sweet cassava accessions, using the UPGMA method, by: A. Mahalanobis' distance (13 quantitative traits) with coefficient of the cophenetic correlation $(\mathrm{r}=0.92)$; B. complement of the simple coincidence index (27 morphological markers) with coefficient of cophenetic correlation $(r=0.89)$; and C. complement of Jaccard's similarity index based on 66 RAPD markers, with a cophenetic correlation coefficient $(r=0.93)$. The dotted line represents the mean distance/ dissimilarity. 
EA Vieira et al.

The 11 RAPD primers generated a total of 118 markers, of which 66 (56\%) were polymorphic (Table 3 ), confirming the existence of genetic variability and efficiency of RAPD in detecting genetic diversity in this set of accessions. The high efficiency of RAPD markers in detecting genetic variability in cassava accessions was already reported by Carvalho and Schaal (2001), Zacharias et al. (2004) and Vieira et al. (2008). The primer that produced most polymorphic bands was OPF-08 with 15 bands, whereas primer $\mathrm{OPH}-13$ produced none (Table 3 ).

The most similar accessions, according to the RAPD markers, were BGMC 1290 and BGMC 1289, two local varieties of the group Taquara Amarela, from Planaltina, DF, and the least similar BGMC 1250 and BGMC 1246, local varieties of the municipalities of Unai (MG) and Brazlândia (GO), respectively (Table 1). By a visual analysis of Figure 1C, using the dissimilarity mean as cutoff, the accessions were clustered into five groups: i) BGMC 34, BGMC 1096 and BGMC 1254; ii) BGMC 751 and BGMC 1246; iii) BGMC 753, BGMC 764, BGMC 1341, BGMC 962, BGMC 1290, BGMC 1289, BGMC 1291, BGMC 1292 and BGMC 1266; iv) BGMC 982; and v) BGMC 1250. The cophenetic correlation coefficient of the dendrogram ( $r=0.93$ ) showed a good adjustment of the graphical representation of genetic dissimilarity and the original matrix, which corroborates the inferences based on visual assessment of Figure 1C.

Among the accessions tested, four belong to a phenotypically very similar group, which is popularly known as Taquara Amarela group (BGMC 1289, BGMC 1290, BGMC 1291, and BGMC 1292) and were originally introduced into the BGMC as different in agronomic potential. The results showed the existence of variability in quantitative traits among accessions, in the traits PRA, ShW, StW, RY, RSt, HFB, NL, CLF and PL and only for the traits $\mathrm{PH}, \mathrm{CT}, \mathrm{BBI}, \mathrm{BBS}$, and WLL no variability was found (Table 2). Quality traits and molecular markers also detected variation in these accessions (Figures $1 \mathrm{~B}$ and $1 \mathrm{C}$ ), which shows that these genotypes are not completely similar. The multivariate analysis of quantitative traits (Figure 1A) revealed that the group of accessions known as Taquara Amarela is very close to two cultivars named Pioneira BGMC 982 and BGMC 1341. This result is very interesting, since BGMC 982 is recommended for cultivation in the Cerrado region (Vieira et al. 2009). Consequently, the accessions of group Taquara Amarela might also be suitable for cultivation in the region after testing in different environments.

The highest correlation was found between the genetic divergence estimated by qualitative characters and molecular markers $(r=0.64)$ and between qualitative and quantitative traits $(r=0.51)$. These values are highly significant, according to the Mantel matrix comparison test with 1000 permutations, but of intermediate magnitude. On the other hand, the association of the genetic distance matrix estimated by quantitative characters with the dissimilarity matrix obtained from RAPD $(r=0.25)$ was significant $(\mathrm{P}<0.05)$, but of low magnitude.

The phenotypic similarity (morphological and agronomic) of the accessions known as Pioneira (BGMC 982 and BGMC 1341) was high, whereas low similarity was observed by the molecular markers between these accessions (Figures 1A, 1B and 1C), indicating that despite the phenotypic similarity of the accessions, the origin is not the same. All three techniques detected the presence of a grouping formed by local accessions of group Taquara Amarela(BGMC 1289, BGMC 1290, BGMC 1291, and BGMC 1292), indicating a common origin of these accessions. Thus, crossings between the accessions of group Taquara Amarela should be avoided in breeding.

\section{ACKNOWLEDGEMENTS}

The authors thank to Embrapa, Fundação Banco do Brasil, CNPq and Biodiversity Program Brazil - Italy for the financial support. 


\title{
Characterization of sweet cassava accessions based on molecular, quantitative and qualitative data
}

\begin{abstract}
RESUMO - O objetivo desse estudo foi estimar a divergência genética entre acessos de mandioca de mesa por meio de marcadores moleculares e de caracteres quantitativos e qualitativos, bem como determinar a correlação entre essas estimativas. Foram avaliados dezesseis acessos de mandioca de mesa integrantes do Banco Regional de Germoplasma de Mandioca do Cerrado. Os acessos foram avaliados a campo quanto a 13 caracteres quantitativos e 33 caracteres qualitativos e em laboratório usando marcadores RAPD. Foram estimadas as matrizes de dissimilaridade/distância genética entre os acessos por meio dos caracteres qualitativos e quantitativos e a significância da correlação entre as matrizes. Os resultados revelaram a existência de elevada divergência entre os acessos quanto a marcadores RAPD, caracteres qualitativos e quantitativos. A divergência estimada por meio de marcadores moleculares e caracteres quantitativos revelaram reduzida associação entre si e moderada com a estimada por meio de caracteres qualitativos.
\end{abstract}

Palavras-chave: Manihot esculenta Crantz; recursos genéticos; melhoramento genético; variabilidade genética.

\section{REFERENCES}

Andersen MD, Busk PK, Svendsen I and Moller BL (2000) Cytochromes P-450 from cassava (Manihot esculenta Crantz) catalyzing the first steps in the biosynthesis of the cyanogenic glucosides linamarin and lotaustralin. Journal of Biological Chemistry 275: 1966-1975.

Bolhuis GG (1954) The toxicity of cassava roots. Netherlands Journal of Agricultural Science 2: 176-185.

Borges MF, Fukuda WMG and Rossetti AG (2002) Avaliação de variedades de mandioca para consumo humano. Pesquisa Agropecuária Brasileira 37: 1559-1565.

Carvalho LJCB and Schaal BA (2001) Assessing genetic diversity in the cassava (Manihot esculenta Crantz) germplasm collection in Brazil using PCR-based Markers. Euphytica 120: 133-142.

Ceballos H, Iglesias CA, Pérez JC and Dixon AGO (2004) Cassava breeding: opportunities and challenges. Plant Molecular Biology 56: 503-516.

Cock J (1985) Cassava - new potential for a neglected crop. Westview Press, Boulder, 240p.

Colombo C, Second G and Charrier A (2000) Diversity within American cassava germplasm based on RAPD markers. Genetics and Molecular Biology 31: 189-199.

Costa AM, Faleiro FG, Karia CT, Shiratsuchi LS, Andrade RP and Lopes GKB (2005) Variabilidade genética e ecológica de Stylosanthes macrocephala determinadas por RAPD e SIG. Pesquisa Agropecuária Brasileira 40: 899-909.

Cruz CD (2001) Programa genes: aplicativo computacional em genética e estatística. Editora UFV, Viçosa, 642p.

El-Sharkawy MA (2003) Cassava biology and physiology. Plant Molecular Biology 53: 621-641.

Crop Breeding and Applied Biotechnology 11: 232-240, 2011
Faleiro FG, Faleiro ASG, Cordeiro MCR and Karia CT (2003) Metodologia para operacionalizar a extração de DNA de espécies nativas do cerrado. Embrapa Cerrados, Planaltina, $6 \mathrm{p}$.

Ferreira CF, Alves E, Pestana KN, Junghans DT, Kobayashi AK, Santos VJ, Silva RP, Silva PH, Soares E and Fukuda W (2008) Molecular characterization of cassava (Manihot esculenta Crantz) with yellow-orange roots for beta-carotene improvement. Crop Breeding and Applied Genetics 8: 2329.

Fukuda WMG and Guevara CL (1998) Descritores morfológicos e agronômicos para a caracterização de mandioca (Manihot esculenta Crantz). Embrapa Mandioca e Fruticultura Tropical, Cruz das Almas, 38p.

Grossmann J and Freitas AG (1950) Determinação do teor de matéria seca pelo método peso específico em raízes de mandioca. Revista Agronômica 14: 75-80.

Jaccard P (1908) Nouvelles recherches sur la distribution florale. Bulletin Société Vaudoise des Sciences Naturelles 44: 223-270.

Mahalanobis PC (1936) On the generalized distance in statistics. Proceedings of the National Institute of Sciences of India 2: $49-55$.

Mantel N (1967) The detection of disease clustering and a generalized regression approach. Cancer Research 27: 209220.

Mkumbira J, Chiwona-Karltun L, Lagercrantz U, Mahungu NM, Saka J, Mhone A, Bokanga M, Brimer L, Gullberg U and Rosling H (2003) Classification of cassava into "bitter" and "cool" in Malawi: from farmer's perception to characterisation by molecular markers. Euphytica 132: 7-22. 
EA Vieira et al.

Nick C, Carvalho M, Assis LHB and Carvalho SP (2008) Genetic dissimilarity in cassava clones determined by multivariate techniques. Crop Breeding and Applied Biotechnology 8: 104-110.

Olsen KM (2004) SNPs, SSRs and inferences on cassava's origin. Plant Molecular Biology 56: 517-526.

Ramos JGA and Takatsu A (1987) Avaliação da resistência de cultivares de mandioca à bacteriose em Goiás. EMGOPA, Goiânia, 26p.

Rohlf FJ (2000) NTSYS-pc: numerical taxonomy and multivariate analysis system, version 2.1. Exeter Software, New York, 98p.

Scott AJ and Knott MA (1974) A cluster analysis methods for grouping means in the analysis of variance. Biometrics 30: 507-512.

Sokal RR and Rohlf FJ (1962) The comparison of dendrograms by objective methods. Taxon 11: 30-40.
Souza LS and Fialho JF (2003) Sistema de produção de mandioca para a região do cerrado. Embrapa Mandioca e Fruticultura Tropical, Cruz da Almas, 61p.

Vieira EA, Fialho JF, Faleiro FG, Bellon G, Fonseca KG, Carvalho LJCB, Silva MS, Moraes SVP, Santos Filho MOS and Silva KN (2008) Divergência genética entre acessos açucarados e não açucarados de mandioca. Pesquisa Agropecuária Brasileira 43: $1707-1715$

Vieira EA, Fialho JF, Silva MS, Fukuda WMG and Santos Filho MOS (2009) Comportamento de genótipos de mandioca de mesa no Distrito Federal. Ciência Agronômica 40: 113-122.

Williams HJ and Edwards TG (1980) Estimation of cyanide with alkaline picrate. Journal of the Science of Food and Agriculture 31: 15-22.

Zacarias AM, Botha AM, Labuschagne MT and Benesi IRM (2004) Characterization and genetic distance analysis of cassava (Manihot esculenta Crantz) germplasm form Mozambique using RAPD fingerprinting. Euphytica 138: 49-53. 